Jpn. J. Oral Biol., $31:$ 35-43, 1989.

\title{
ヒト咀嚼筋の差動リサージュ筋電図とその応用
}

\author{
熊井敏 文野 村 浩 道 \\ 松本歯科大学口腔生理学教室
}

〔受付：昭和63年 9 月 9 日〕

\section{Differential Lissajous EMG of masticatory muscles and its application in man}

\author{
Toshifumi Kumai and Hiromichi Nomura \\ Department of Oral Physiology, Matsumoto Dental College, \\ Goobara, Hirooka, 311, Shiojiri, 399-07, Japan \\ [Accepted for publication: September 9, 1988]
}

Key word : Electromyogram / differential Lissajous EMG / masticatory muscles / mastication

\begin{abstract}
Difference in the activity of masticatory muscles between subjects with normal teeth alighnment and occlusion and patients with disorders at the oral region was investigated using a differential Lissajous EMG method. Surface EMGs were recorded from the right and left temporal and masseter muscles during peanut and chewing gum mastications. The difference of the integrated EMGs between both sides was obtained in both the temporals and masseters, then two differences were synthesized to a Lissajous figure. The figures generally showed the followings. 1) In the normal subjects, the muscle behaviour varied from strkoe to stroke in peanut mastication, while it was constant in chewing gum mastication. 2) Activity of some muscles of the patients was quitely weak, while that of the normal subjects was totally balanced. 3) In the patiens, combination of use between the temporal and masseter muscles and contraction order among the muscles tended to be reversed compared to the normal subjects.
\end{abstract}

\begin{abstract}
緒言
咀嚼運動の解析においては, Moyers (1950) ${ }^{11}$ 以来筋電図が一つの有効な手段としてょく用いら れている。筋電図の 解析方法にはいろいろある が，積分された筋電位を $\mathrm{X}$ 軸と $\mathrm{Y}$ 軸にベクトル合 成し、リサージュパターンとして表現すると異な る二つの筋活動の関連性をよく表現できる ${ }^{2,3)}$ 。こ の方法における咀嚼筋の組み合わせは色々考えら れるが，Kumai 等") は左右咬筋の積分筋電位から 得られたリサージュパターンが各々の咀嚼サイク ルに対応した多くのループ状の軌跡から成り, 全 体のパターンは食品の種類に応じて, よくその咀 嚼傾向を表現していることを示した。 表面筋電図法においては浅層咬筋と 側頭筋前腹
\end{abstract}

長野県塩尻市広丘䐚原311（干399-07）
がよく用いられるが，これらをそれぞれ左右でリ サージュパターンにすると，それぞれの筋の左右 の関連を示すことはできるが，個々の咀嚼サイク ルを対応させて咬筋と側頭筋の活動関連をみるこ とは難しい。そこで Kumai $(1988)^{5)}$ は，このリ サージュ筋電図の方法を更に発展させ 4 筋の 活動

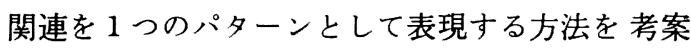
した。この方法は，咬筋の側頭筋でそれぞれの積 分筋電位の左右差をとり，その差分同士をX軸と Y軸にリサージュパターンとして表現するもの で，このことにより筋活動の絶対值は差分に隠れ てしまうが，4筋の活動の相対的な関連を $1 つ の$ 図形で表現できる。今回はこの差動型のリサージ 工筋電図を正常者と歯科領域に何らかの異常を持 つ人に適応し，そのパターンの違いを比較検討し てみた（なお，本論文では筋レベルでのトータル 
な活動電位を便宜上筋電位と呼び, なんらかの図 として表現された笳電図とは区別することにす る)。

\section{方法}

被験者は，顎口腔系に異常がなく歯列の正常な 20〜25歳の男子 4 名と, 異常被験者として (1) 左 上顎 7 番に大きなカリエスを持つ 36 歳の男性, （2）不正咬合（Class III）の 13 歳女子，(3) 疼痛 を伴った原因不明の 左側筫関節障害の32歳の男性 の 3 名を用いた。

筋電位は双極電極（電極間距離 $4 \mathrm{~cm}$ ）を用いて 左右の浅層咬筋中央部と左右の側頭筋前腹の皮膚 表面より同時に導出された。得られた筋電位は増 幅, 整流した後, RC 回路（時定数 $0.1 \mathrm{sec）で}$ 平滑化し， $\mathrm{A} / \mathrm{D}$ コンバーターを通してコンピュ ーターシステム（PC-9801，NEC）に取込んだ。 取込んだデーターはいずれのチャンネルとも 18 $\mathrm{sec}$ 間（1800ポイント， $10 \mathrm{~m} \mathrm{sec}$ 間隔）である。 電極の貼付部位やアナログ回路の増幅度には左右 のチャンネル間で差が生じないように注意を払っ た。

積分筋電位のデータは，まず咬筋と側頭筋でそ れぞれの右側積分筋電位から左側積分筋電位を引 くことにより差分を求めた（以下これを差動積分 筋電位 (図) と呼ぶ)。次に咬筋と側頭筋の差動積 分筋電位をそれぞれX/Y プロッターの $\mathrm{X}$ 軸と $\mathrm{Y}$ 軸にプロットしリサージュ図形として表現した (以下これを差動リサージュ筋電図と呼ぶ)。咀嚼 運動の経時変化をみるため, 必要な場合は差動り サージュ図形を個々の咀嚼サイクルごとに分解し た。またパターンを数量的な観点から把握するた めに 4 筋の積分筋電図のそれぞれの総面積 と側頭 筋，咬筋の左右の相関係数を計算した。総面積は 側頭筋の左右の合計值を100とした 時の個々の筋 の相対值で表した。相関係数を求める際には全体 を $3 \mathrm{sec} こ ゙ と に 6$ 分割してそれぞれの部分での值 を平均した。（これは例えばチューインガムのよ うな場合咀嚼は左右に分離するので相関が全体と して負になってしまい，これを避けるためであ る。従って18秒間全体の相関とはかなり異なる場 合がある。)
用いた食品はピーナツ（3 個, 約 $3 \mathrm{~g}$ ) とチュ ーインガム $(3.1 \mathrm{~g})$ で, チューインガムは口中で 柔らかくなってからデーターをとった。ピーナツ は自由に咀嚼してもらったが，チューインガム咀 嚼の際は, $9 \mathrm{sec}$ 後に作業側を換えるよう指示し た。

\section{結果}

Fig. $1 \mathrm{~A}$ は正常者のピーナツ咀嚼時の側頭筋 と咬筋の積分筋電図とそれぞれの筋の差動積分筋 電図 (Diff.) である。側頭筋のパターンは左右で 余り差がみられないが咬筋の活動は平衡側の 筋電 位が作業側にくらべ顕著に小さく，全体的に変化 に富んでいる（側頭筋の咬筋の左右間の相関係数 はそれぞれ0.95と0.70)。この傾向はそれぞれの 差動積分筋電図によく表われていて，咬筋のもの は側頭筋に比べ振幅が大きい（もちろん差動積分 筋電位の大きさは，それぞれの筋の増幅度に依存 するが，この場合，咬筋の左右積分筋電位の総面 積は側頭筋より小さかった (0.86倍))。Fig. $1 \mathrm{~B}$ は側頭筋と咬筋の差動積分筋電位をリサージュ合 成したものである。ピーナツの差動リサージュ筋 電図は様々な形をした多数のループ状の 軌跡より 成るが，多くはX (咬筋) 軸の方向に伸びている。 また，全体のパターンは明らかに咀嚼サイドと対 応していると思われる右側と左側のループ群に 分 れている。図1 C はBのリサージュ筋電図を時間 経過に従って個々のサイクルに分解したものであ る。一般的な傾向として, 個々のサイクルはまず 作業側の咬筋と側頭筋の領域に進行し，時計方向 に回転（右回転）しながら後半は平衡側の側頭筋 の領域に侵入した後原点に戻る。このような軌跡 パターンは特に幅広のループに見られた。しかし 個々のサイクルではループの形にかなり違いがあ る。また幅の狭いループは複雑な動きをし必ずし も右回転しない。

Fig. 2 A はFig. 1 と同じ被験者のチューイン ガム咀嚼の際の側頭筋と咬筋の積分筋電図とその 差動積分筋電図である（側頭筋と咬筋の総面積比 は100対64)。この場合は側頭筋でも左右でピーク の電位に差はみられるが，咬筋の平衡側筋電位は 非常に小さい（相関係数は側頭筋が 0.87, 咬筋が 


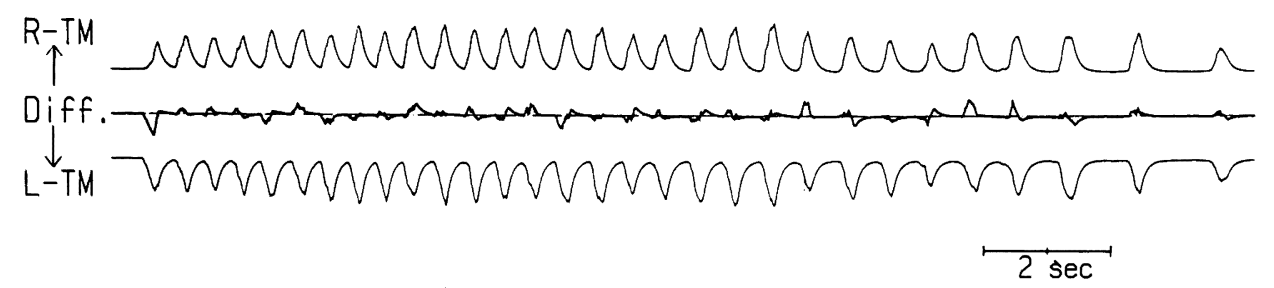

A
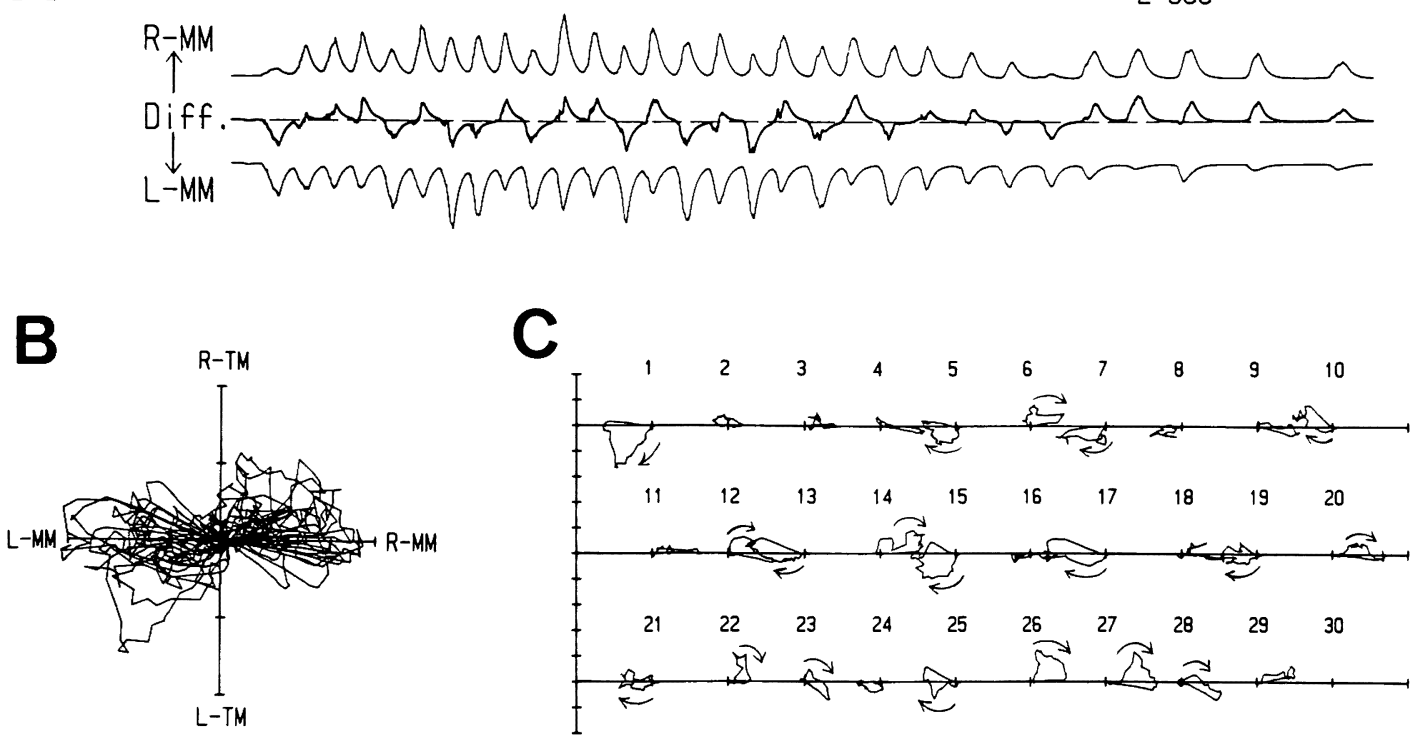

Fig. 1 A : Integrated EMGs of the anterior part of the temporal muscle (TM) and the superficial masseter muscle (MM) on the right (R-) and left (L-) sides during peanut mastication, and the differences (Diff.) between the symmetrical muscles. Note that the left IEMGs are inverted to allow the differences to be obtained. B: The Lissajous figure synthesized from the differential integrated EMGs. C: The first 30 individual cycles of the differential Lissajous figure which were sequentially isolated. Allows the direction of the rotation of the trajectories to be indicated.

0.69)。Fig. 2B はAの差動リサージュ筋電図であ る。この場合個々のループの形と方向がよく似て いて，ほほ同じ場所に単調な軌跡を描いている。

Fig. 2C はこれを個々のサイクルに分解したもの だが，ループは右側咀嚼のものも左側咀嚼のもの も右回転する。しかしピーナツの場合と異なりサ イクル後期の平衡側側頭筋領域への侵入はみられ ない。

Fig. 3 は他の正常者三人のピーナッとチューイ ンガム咀嚼時の差動リサージュ筋電図である。一 般にピーナッのパターンはチューインガムのもの より被験者によるバリエーションが大きいように 思われる。ピーナッのパターンは三者共, 左右両 方の咀嚼がみられるが, 被験者 Cの右側咀嚼のサ イクルは小さく，また，側頭筋も左側の活動が優
勢であることを示していた。ガムのパターンは三 者共似ていて左右のループの方向と形が割合そろ

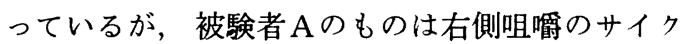
ルが左側咀嚼のものよりかなり長い。Table 1 は これら三者の積分筋電図の面積の相対值と相関を 示したものである。傾向としては筋電図の面積は 左右間で極端な差はなく相関は咬筋のほうが側頭 筋より小さい。

Fig. 4 は口顎系に障害を持つ 3 人の差動リサー ジュ筋電図である。A $\mathrm{A}$ は上鿓左 7 番に大きなカリ エスを持つ者のパターンである。ピーナッのパタ ーンはループが咬筋軸に沿って右側に集中してい る。また，個々のループはほとんどが正常者とは 異なる左回転を示した。チューインガムのパター ンは左側咀嚼のものが著しく短く形も右咀嚼のも 

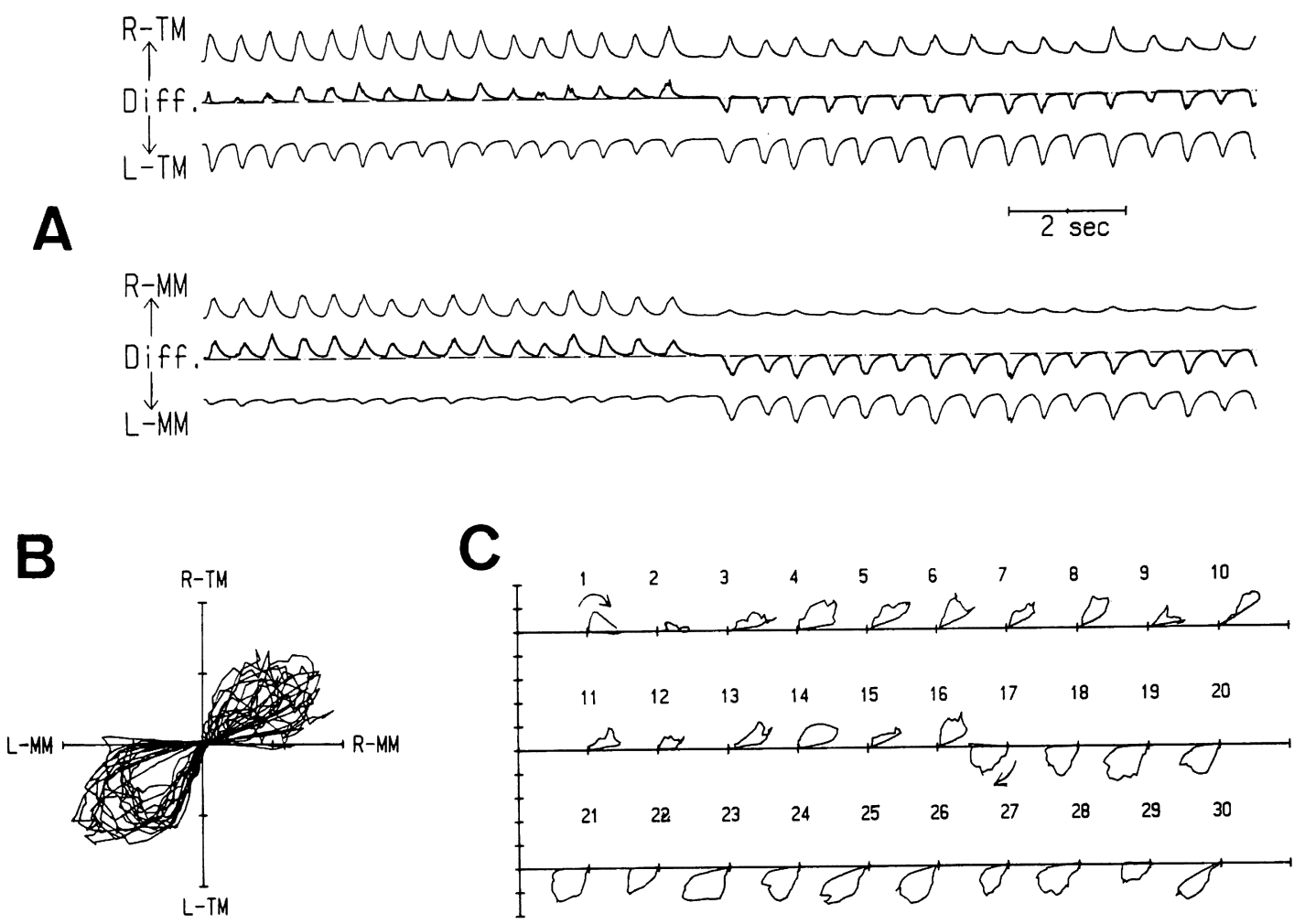

Fig. $2 \mathrm{~A}$ : Integrated EMGs of the anterior part of the temporal muscle (TM) and the superficial masseter muscle (MM) on the right (R-) and left (L-) sides during chewing gum mastication, and the differences (Diff.). between the symmetrical muscles. Note that the left IEMGs are inverted to allow the differences to be obtained. B: The Lissajous figure synthesized from the differential integrated EMGs. C: The first 30 individual cycles of the differential Lissajous figure which were sequentially isolated. Allows the direction of the rotation of the trajectories to be indicated.

のとかなり異なる。回転の方向は左側咀嚼の場合 は右回転だったが 右側咀嚼のものは左回転を示し た。Bは不正咬合者（Class III）のものだがピーナ ツのパターンは右側咬筋と左側側頭筋の 領域に集 中している。個々のループは著しく幅が狭く回転 は主に左方向を示した。チューインガムのパター ンも個々のループの幅が狭くしかも右側咀嚼のも のも左側咀嚼のものも側頭筋の使い方が逆であ る。またガム咀嚼特有の個々のループの定常性が 低く軌跡は複雑である。Cは左側に顎関節障害の ある者のパターンである。この場合もピーナッ咀 嚼のループは右側だけとなっているが 回転は右回 転で正常だった。また，チューインガムのパター ンは左側咀嚼の時だけ側頭筋の使い方が逆になっ ていて長さも短く軌跡が複雑である。回転はどち
らの側のものも右回転を示した。Table 2 はこれ ら三者の積分筋電図の面積の相対値と 相関倸数を 示したものであるが特に面積に左右のアンバラン スが現れている。

\section{考察}

咀嚼時における側頭筋と咬筋の収縮順序は一般 的にはまず作業側の側頭筋が収縮を開始し，つい で同側の咬筋が続き，ほぼ同時にピークに達した 後減少に転じるが，平衡側の側頭筋は収縮が最後

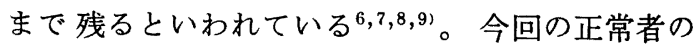
ピーナツの差動リサージュ筋電図に拄いては多く のループが右回転を示し，又後半で反対側の側頭 筋領域に侵入する傾向を示した。これは上述の側 頭筋と咬筋の行動を強く示唆するものだが 特に幅 

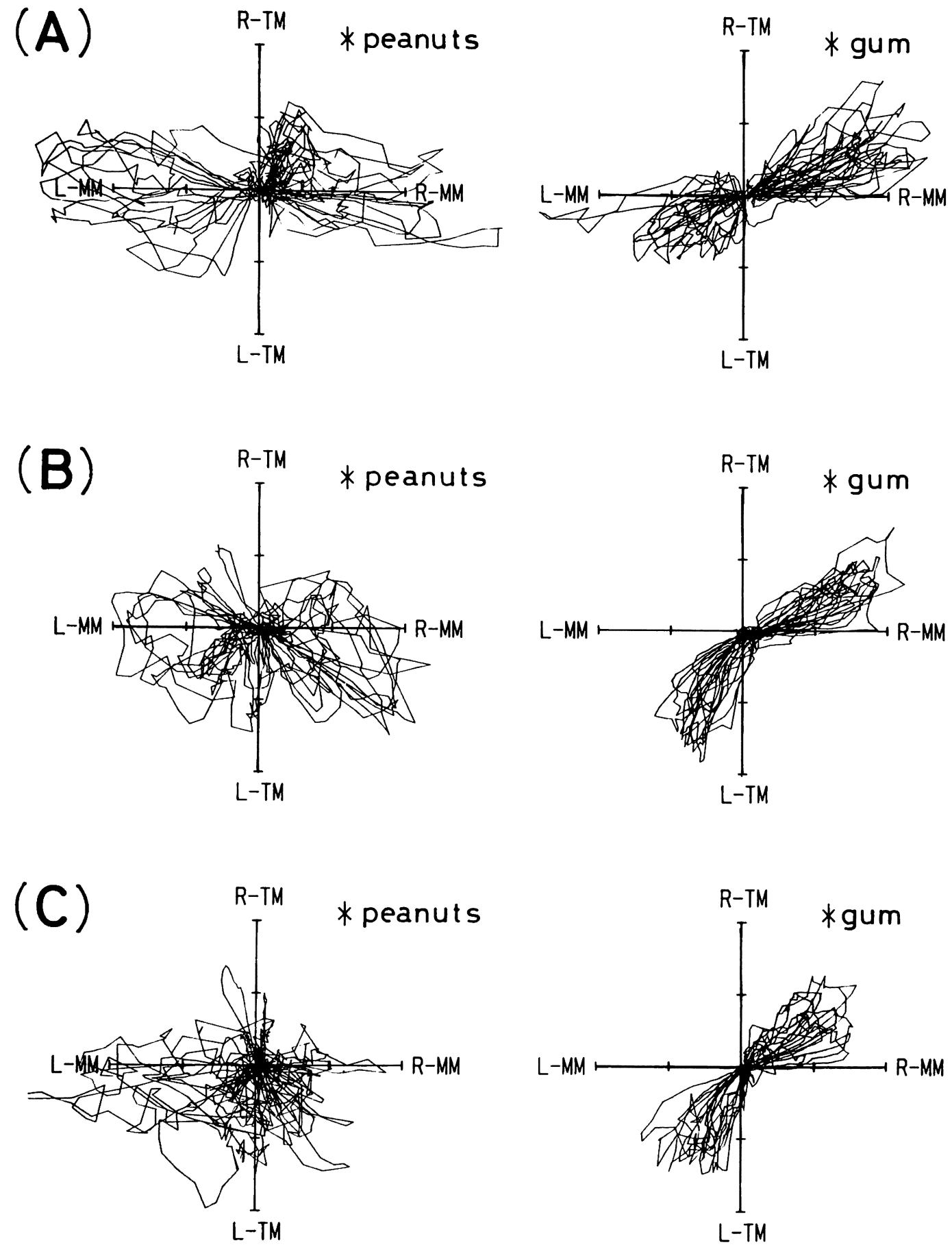

Fig. 3 Differential Lissajous figures for peanut and chewing gum (gum) of three subjects (A, B, C) with normal tooth alignment and occlusion. R-TM and L-TM=right and left temporal muscle, $\mathrm{R} \cdot \mathrm{MM}$ and $\mathrm{L} \cdot \mathrm{MM}=$ right and left masseter muscle. 
Table 1 Proportion (p) of amplification of the temporal signal to the masseter, relative value of area (a) of the integrated EMGs, and correlation( $r$ ) between the paired EMGs in peanut and chewing gum (gum) mastications of three normal subects.

\begin{tabular}{|c|c|c|c|c|c|c|c|}
\hline \multirow{2}{*}{$\mathrm{p}$} & \multirow{2}{*}{$\mathrm{TM} / \mathrm{MM}$} & \multicolumn{2}{|c|}{ A } & \multicolumn{2}{|c|}{ B } & \multicolumn{2}{|c|}{ C } \\
\hline & & \multicolumn{2}{|c|}{0.5} & \multicolumn{2}{|c|}{0.7} & \multicolumn{2}{|c|}{0.5} \\
\hline \multirow{3}{*}{ a } & & peanut & gum & peanut & gum & peanut & gum \\
\hline & $\begin{array}{l}\text { R.TM } \\
\text { L-TM }\end{array}$ & $\left.\begin{array}{l}51 \\
49\end{array}\right\} 100$ & $\begin{array}{l}52 \\
48\end{array}\{100$ & $\left.\begin{array}{l}46 \\
54\end{array}\right\} 100$ & $\left.\begin{array}{l}45 \\
55\end{array}\right\} 100$ & $\left.\begin{array}{l}48 \\
52\end{array}\right\} 100$ & $\left.\begin{array}{l}47 \\
53\end{array}\right\} 100$ \\
\hline & $\begin{array}{l}\text { R-MM } \\
\text { L-MM }\end{array}$ & $\left.\begin{array}{l}39 \\
37\end{array}\right\} 78$ & $\left.\begin{array}{l}37 \\
23\end{array}\right\} 60$ & $\left.\begin{array}{l}51 \\
41\end{array}\right\} 92$ & $\left.\begin{array}{l}52 \\
33\end{array}\right\} 85$ & $\left.\begin{array}{l}50 \\
50\end{array}\right\} 100$ & $\left.\begin{array}{l}38 \\
27\end{array}\right\} 65$ \\
\hline \multirow{2}{*}{$\mathrm{r}$} & R-TM $*$ L-TM & 0.97 & 0.94 & 0.94 & 0.89 & 0.89 & 0.95 \\
\hline & $\mathrm{R}-\mathrm{MM} * \mathrm{~L}-\mathrm{MM}$ & 0.74 & 0.66 & 0.74 & 0.74 & 0.94 & 0.95 \\
\hline
\end{tabular}

* Correlations were averaged among six parts of the sequences.

* R-, L-, TM, MM=right, left, temporal muscle and masseter muscle.

* Subjects A, B and C correspond respectively to those of (A), (B) and (C) in Fig. 3.

広のループでこれが強くみられた。しかし,このよ うな軌跡傾向を示すループにおいても形はバリエ ーションに富んでいて側頭筋と咬筋の活動連関が 画一的でなく，咀嚼ごとにかなり変化することを 示している。またループの形から作業側の咬筋と 側頭筋の活動が同時にピークに達するという点に はピーナツ咀嚼の場合疑問が残る。チューインガ ムのパターンは，正常者では個々のサイクルがよ く似ていてバリェーションは余り無い。又, ルー プの後期に反対側の側頭筋に侵入がみられないこ とから咀嚼サイクル後期の側頭筋の活動は明らか に同側の方が優勢である。更にループの形からチ ューインガム咀嚼の場合は作業側の 側頭筋と咬筋 の活動はほぼ同時にピークに達すると思われる。 Sicher $(1980)^{10)}$ は筋の走向や生理学的性質から 側頭筋は主に下䫟の位置決めとして働き，実際の 仕事は咬筋が主体であることを示唆している。ピ ーナツ咀嚼の場合臼磨動作で横にスライドした下 顎を中心咬合位に戻さなければならないが，チュ ーインガム咀嚼の場合は 同側で連続して咀嚼する のでその必要はないと考えれば，今回見出された 両食品の差動リサージュパターンは確かに側頭筋 の下顎の位置決めとしての側面を強く支持してい る。

ところで正常な咀嚼とは何かという問題には咀 嚼動作における個人間のバリエーションが関係し
ているので筋電図学的な定義は難しいが，今回の 4 人の正常者のパターンと 3 人の異常者のパター ンを比較すると以下のような考察が可能である。

1）異常者のピーナッ咀嚼ではほとんどのループ が座標の特定の部分に集中する。これは筋活動の バランスがいずれかの筋に片寄っていることを示 し，障害のある側を避けて咀嚼するか，あるいは 障害のある側での咀嚼にはカがはいらないことが 原因と思われる。ガム咀嚼でも障害のある側のル ープは小さい。不正咬合者の場合は下顎の動きが ある範囲内でロックされてしまうので，正常な人 より習慣性咬合が増強されやすいことが原因とお もわれる。2）異常者のパターンは作業時におけ る側頭筋と咬筋の組み合わせが正常者のものと逆 になる場合がある。このような咀嚼傾向は以前か ら不正咬合でよく報告されており ${ }^{6,8,11,12)}$ ，今回も 不正咬合者のパターンに顕著にみられた。また顎 関節障害者のガム咀嚼のパターンでも障害のある 側での咀嚼の際の側頭筋の使われかたが逆だった が，このような障害が側頭筋の活動に反映されて くるのは興味深い点である。カリエスの患者では 使われる筋の組み合わせは正常者と同じだったが 個々のループの 回転方向が反対になる場合があ り，やはり側頭筋と咬筋の活動のしかたが正常者 とは異なることが推察される。3）一般に 異常者 に比べて正常者の個々のループはピーナッのもの 

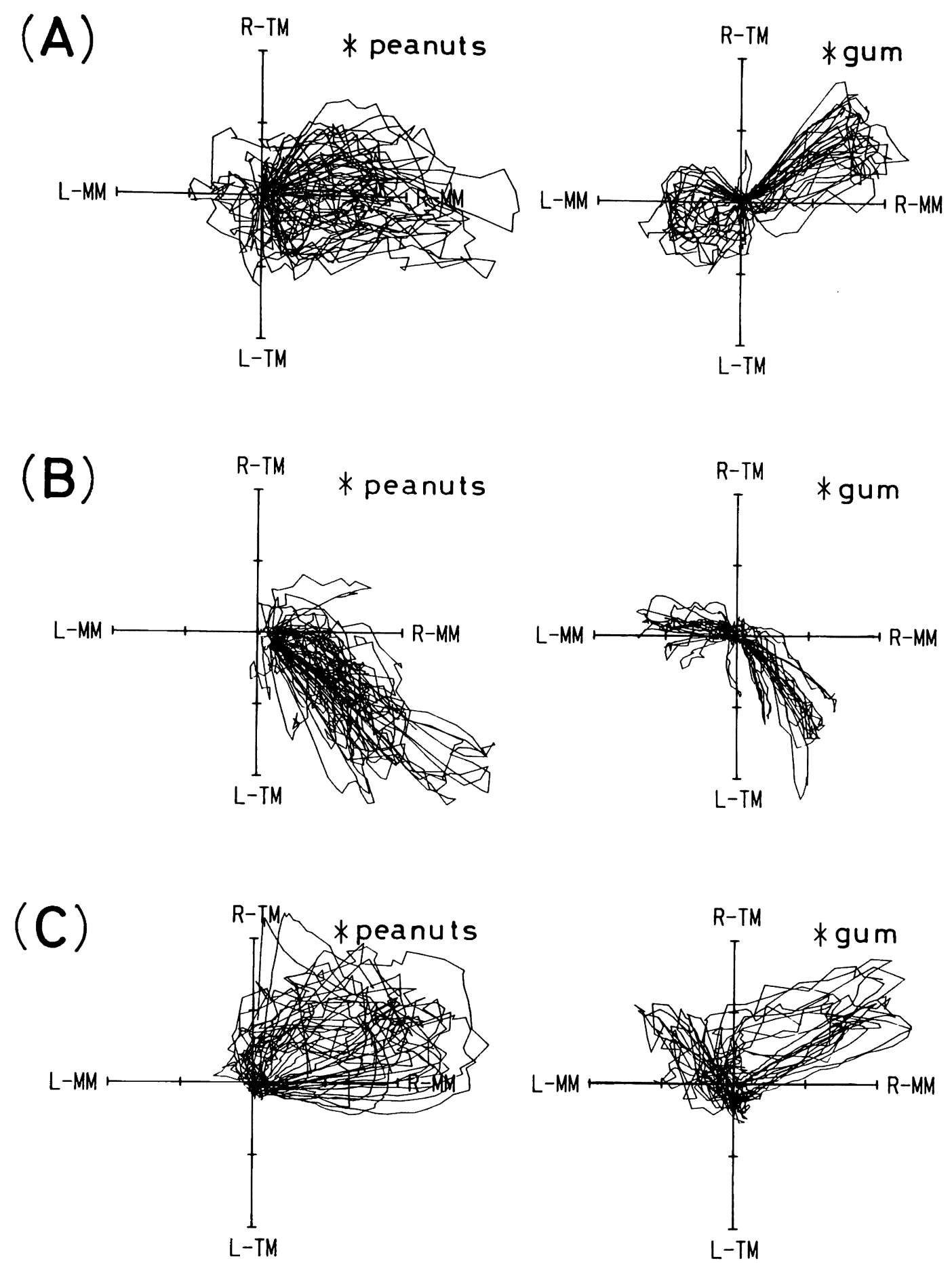

Fig. 4 Differential Lissajous figures for peanut and chewing gum (gum) of three patients. (A) is the figures for a patient with deep caries at the upper second molar. (B) is the figures of a malocclusion patient (class III). (C) is the figures of a patient with temporo-mandibular joint disfunction on the left side. 
Table 2 Proportion ( $p$ ) of amplification of the temporal signal to the masseter, relative value of area (a) of the integrated EMGs, and correlation ( $r$ ) between the paired EMGs in peanut and chewing gum (gum) mastications of three patients

\begin{tabular}{|c|c|c|c|c|c|c|c|}
\hline \multirow{2}{*}{$\mathrm{p}$} & \multirow{2}{*}{$\mathrm{TM} / \mathrm{MM}$} & \multicolumn{2}{|c|}{ A } & \multicolumn{2}{|c|}{ B } & \multicolumn{2}{|c|}{$\mathrm{C}$} \\
\hline & & \multicolumn{2}{|c|}{0.5} & \multicolumn{2}{|c|}{0.4} & \multicolumn{2}{|c|}{0.5} \\
\hline \multirow{3}{*}{ a } & & peanut & gum & peanut & gum & peanut & gum \\
\hline & $\begin{array}{l}\text { R-TM } \\
\text { L-TM }\end{array}$ & $\left.\begin{array}{l}50 \\
50\end{array}\right\} 100$ & $\left.\begin{array}{l}54 \\
46\end{array}\right\} 100$ & $\left.\begin{array}{l}36 \\
64\end{array}\right\} 100$ & $\left.\begin{array}{l}42 \\
58\end{array}\right\} 100$ & $\left.\begin{array}{l}56 \\
44\end{array}\right\} 100$ & $\left.\begin{array}{l}54 \\
46\end{array}\right\} 100$ \\
\hline & $\begin{array}{l}\text { R-TM } \\
\text { L-MM }\end{array}$ & $\left.\begin{array}{l}49 \\
42\end{array}\right\} 91$ & $\left.\begin{array}{l}29 \\
21\end{array}\right\} 50$ & $\left.\begin{array}{c}58 \\
15\end{array}\right\} 73$ & $\left.\begin{array}{l}36 \\
33\end{array}\right\} 69$ & $\left.\begin{array}{l}62 \\
28\end{array}\right\} 90$ & $\left.\begin{array}{l}42 \\
34\end{array}\right\} 76$ \\
\hline \multirow{2}{*}{$\mathbf{r}$} & $\mathrm{R}-\mathrm{TM} * \mathrm{~L}-\mathrm{TM}$ & 0.96 & 0.97 & 0.79 & 0.86 & 0.89 & 0.95 \\
\hline & $\mathrm{R}-\mathrm{MM} * \mathrm{~L}-\mathrm{MM}$ & 0.80 & 0.89 & 0.76 & 0.89 & 0.72 & 0.87 \\
\hline
\end{tabular}

* Correlations were averaged among six parts of the sequences.

* R., L-, TM, MM=right, left, temporal muscle and masseter muscle.

* Subjects A, B and C are correspond respectively to those of (A), (B) and (c) in Fig. 4.

はバラエティーに富み, ガムのものは逆に定常性 が高い。（しかしこの点は個々の症例によってか なり差があるのでもっと多くの例で検討してみる 必要はある)。

ところで本方法により描かれる作動リサージュ パターンは側頭筋と咬笳の増幅度が $\mathrm{X}$ 軸と $\mathrm{Y}$ 軸の 比率に直接影響を与えるので異なった被検者間で の比較には注意を要する。また筋活動量や咀緭り
ズムも直接みることは出来ない。しかし原波形と 併用して臨床的に応用すれば，特に個々の患者に おける治療前後の咀嚼状態の変化を見るといった ような目的に対してはかなり有益な情報を与えて くれるように思われる。今後, 他の種々の被検者 で筋の組み合わせも変えてみて，筋活動様式と障 害との関連を更に調べてみる予定である。

抄録 : ヒトの左右側頭筋と左右咬笳から筋電位を同時導出し積分した後, 差動型のリサージュ筋電図を求 め, 正常者と顎口腔系になんらかの異常のある人で咀嚼筋の行動にどのような違いがあるかを比較検討した。 実験に供した食品はピーナッツとチューインガムだが，リサージュパターンは咀緭時における 4 筋の活動の 関連性をよく表現していた。正常者では一般に言われている側頭筋と咬筋の活動様式が確認されたが,個々の サイクルではバリエーションがあり例外も多かった。異常者の主な特微としては，1）特定の筋の活動が著し く低い。2）咀嚼時における側頭筋と咬筋の全体組み合わせ，あるいは収縮順序が正常者と逆になる場合があ る。3）ガム咀嶰における筋活動の定常性が低い，等が観察された。

\section{文献}

1) Moyers, R. E.: An electromyographic analysis of certain muscles involved in tem. poro-mandibular movement. A. J. Orthodontol. 36 : 481-515. 1950.

2) Yamashina, T., Arata, K., Munehisa, N., Nagasawa, T. and Tsuru, H.: A new Analysing method of the electromyogram-On the vectormyogram. J. Jpn. Prothod. Soc. 21 : 520-524, 1977.

3) Yamashina, T., Fuji, H., Munehisa, N.,
Nagasawa, T. and Tsuru, H.: Effects of the oral sensory function on the activities of masticatory muscles. J. Jpn. Prothod. Soc. 21 : 525-532, 1977.

4) Kumai, T., Masuda, T., Sadoyama, T. and Nagamura, N.: Lissajous figure method for ascribing masticatory movements. Jpn. J. Oral Biol. 28 : 383-387, 1986.

5) Kumai, T.: Lissajous figures of differential electromyograms of the paired temporal and paired masseter muscles in mastication. Arch. Oral Biol, 33 : 851-854, 1988. 
6) Pruzansky, S.: The application of electromyography to dental researh. J. Am. Dent. Assoc. 44 : 49-68, 1952.

7) Perry, H. T. and Harris, S. C.: Role of the neuromuscular system in functional activity of the mandible. J. Am. Dent. Assoc. 48: 665-673, 1954.

8) Ahlgren, J.: Mechanism of mastication. A quantitative cinematographic and electromyographic study of masticatory movements in children, with special reference to occlusion of the tooth. Acta Odontol. Scand. 24 : Suppl. 44: 1-109, 1966.

9) Moller, E.: The chewing apparatus. An electromyographic study of the action of the muscles of mastication and its correlation with facial morphology. Acta Physiol. Scand. 69 : Suppl. 280. 1-229, 1966.

10) Sicher, H.: Oral Anatomy, 7 th edn Chap. 3 , p. 142. The C. V. Mosby Company, St. Louis., 1980.

11) Perry, H. T.: Functional electromyography of the temporal masseter muscles in class II, division 1, malocclusion and excellent occlusion. Angle Orthod. 25 : 49-58, 1955.

12) Kawamura, Y., Kishi, K., Nobuhara, M. and Fujimoto, J.: Studies on masticatory function. I : An electromyographic analysis of the chewing pattern of the normal occlusion and malocclusion. Med. J. Osaka Univ. 8 : 229-240, 1957. 